\title{
î日
}

International Interdisciplinary

Business-Economics Advancement Journal

ISSN 2375-9615 (online)

ISSN 2375-9607 (print)

\section{Restoring the relevance: Conceptualizing a collaboration model for business schools}

Obed Rashdi Syed

University Teknologi Malaysia

Rosmini Omar

University Teknologi Malaysia

\section{Recommended Citation}

Syed, O. R., \& Omar, R. (2016). Restoring the relevance: Conceptualizing a collaboration model for business schools. International Interdisciplinary Business-Economics Advancement Journal, 1(2), 85-93. 


\title{
Restoring the Relevance: Conceptualizing a Collaboration Model for Business Schools
}

\author{
Obed Rashdi Syed ${ }^{1}$ and Rosmini Omar ${ }^{2}$
}

\author{
International Business School \\ University Teknologi Malaysia, Malaysia \\ 10baidrashdi@hotmail.com \\ ${ }^{2}$ rosmini@ibs.utm.my
}

\begin{abstract}
There are growing debates on practicality of academic services offered by business schools. Recent studies suggest business schools to collaborate with stakeholders to restore the relevance. However, there is eclipse in the literature with reference to collaboration models that generally maps the linkage of business schools with stakeholders. Potential stakeholders of business schools in this study are discussed in two broad segments, namely, primary and secondary stakeholders. Primary stakeholders are students and alumni, and secondary stakeholders are business organizations, non-business organizations and academic institutions. To understand and specify needs and expectations of stakeholders, business schools first need definite mission and vision. Based on that, business schools could identify those stakeholders who they want to serve through academic services. This study attempts to conceptualize a holistic collaboration model that business schools could adapt and proposes method to develop collaborations with potential stakeholders.
\end{abstract}

Keywords: business schools, collaboration model, business school stakeholders, academic services

\section{Introduction}

The debates on practicality of academic services offered by business schools are mounting in the management literature. Most commonly notified issues ranges from business schools being unprofessional and irrelevant towards serving businesses (Datar, Garvin, \& Cullen, 2011; Ghoshal, 2005; Khurana, 2010; Paton, Chia, \& Burt, 2014) up to being unable to provide ethically and socially responsible graduates and sustainable academic contributions (Muff et al., 2013; Nesteruk, 2012; Rasche \& Gilbert, 2015). These issues have raised pressures on leaders and faculty members of business schools to bridge practical and theoretical ideologies of serving their stakeholders through academic endeavors (Kieser, Nicolai, \& Seidl, 2015). However, one of the major problems with business schools is their unclear focus, specifically in terms of who they consider as potential stakeholders (Thomas, Thomas, \& Wilson, 2013).

Starkey and Tempest (2008) identified three types of services that business schools offer to stakeholders, namely, research, consultancy, and teaching services. We view these services as academic services that business schools collectively offer to their stakeholders. However, the primary driver of academic services is the founding principle, so called mission and vision of business school, which reinforces the school's motivation of serving their potential stakeholders 
(Davis, Ruhe, Lee, \& Rajadhyaksha, 2007). Based on that, business schools could identify and reach those stakeholders to understand their needs and expectations, and then collaboratively work with them to deliver the academic services.

Several recent studies have suggest business schools to collaborate with stakeholders to restore the relevance (Antonacopoulou, 2010; Darabi \& Clark, 2012; Paton et al., 2014; Xie \& Steiner, 2013). However, there is still eclipse in the literature with reference to collaboration models that generally maps the linkage of business schools with potential stakeholders (Dixon, Slanickova, \& Warwick, 2013; Muff, 2013; Selen, 2001). It becomes even darker when view this issue from the contextual perspective, especially for those schools that are not appearing at the global levels (Bruhn, Karlan, \& Schoar, 2010; Napier, Harvey, \& Usui, 2008). Therefore, in this paper we attempt to conceptualize a holistic collaboration model that business schools can adapt to serve their stakeholders.

In following sections, the study discusses on stakeholders of business schools. Potential stakeholders are divided into two broad segments, namely, primary and secondary stakeholders. In the later sections, the study presents a conceptual collaboration model that links business school with stakeholders based on definite vision and mission of the school. Accordingly, the study proposes a methodology that business schools may adapt based on their vision and mission. In the end, the study presents conclusion and recommendation for future studies to expand idea of collaboration in the context of business schools.

\section{Business School Stakeholders}

According to Thomas et al. (2013), key stakeholders of business schools are students, business organizations and employers of business graduates, respectively. However, faculty members, universities, governments and societies are also relative stakeholders influenced by business education and other academic services offered by business schools. In this paper, business students and alumni are perceived as primary stakeholders and other stakeholders as secondary stakeholders of business schools.

\section{Primary Stakeholders: Students and Alumni}

Business students and alumni are the most influenced stakeholders of business schools (Baruch, 2009; Thomas et al., 2013). Insufficient development of students in management education programs eventually makes them ill-equipped to wrangle with complex and multidirectional issues of business and management in real organizations. According to Okunade and Berl (1997), quality of academic programs are predominantly the first step towards strengthening the relationship between students and alma-mater. Quality of mentors and approaches used for instructions are likely to enhance student's involvement in relationship, as it also stimulates the affection later to support the institution in promoting and expanding institutional presence and networking. For this purpose, business school's leaders and faculty members must understand and improve teaching and training methods in management education to effectively develop knowledge and skills of students.

Business schools can get alumni assistance and reflection on management education programs and teaching approaches through collaboration with alumni. Baruch and Sang (2012) studied business graduates' intention to contribute in their business schools after graduation and found 
three factors that motivate them, namely, satisfaction with business education, prestige of institution, and their income. Meaning that, alumni are motivated to have progressive ties with the school when they benefit from the management education programs. Business schools having collaborations with its primary stakeholders could benefit in several ways, for instance, by working with the alumni in different projects and research endeavors, and sharing alumni expertise and experiences with faculty members and existing students (Canales, Massey, \& Wrzesniewski, 2010; Hall, 2011).

\section{Secondary Stakeholders: Business Organizations}

Business schools and business organizations are natural partners since the establishment of first business school in the world (Xie \& Steiner, 2013). When MBA programs were introduced, many mentors appointed to train MBA students were practicing managers and business experts (Friga, Bettis, \& Sullivan, 2003). Partnership between business schools and businesses are basically intended to serve and develop each other through academic research and practical undertakings.

According to Darabi and Clark (2012), business school's collaboration with small and medium enterprises (SMEs) assist both entities in bringing inter-disciplinary learning and gaining economic, social and professional benefits. According to Jain and Stopford (2011), business school's collaboration with multinational corporations will at-least cover two main areas which are difficult for an individual business school to accomplish. Firstly, it connects business managers with academia to identify and solve critical issues faced by businesses at corporate levels, and secondly, it develops practical approaches of graduates through academic programs, so that graduates become better future managers and leaders. Practitioners can also help business schools to bring-in action research (Bartunek, 2007) and theoretical developments (Austin \& Bartunek, 2003) to foster the relevance and benefit business development and sustainability.

\section{Secondary Stakeholder: Academic Institutions}

Academic institutions collaborating with another academic institutions is relatively less discussed area in the literature than academic institutions collaborating with other entities like businesses and other organizations (Duffield, Olson, \& Kerzman, 2013). Generally academic institutions are not designed to collaborate with each other, rather they build their own mission and vision to differentiate and compete with other institutions in order to gain recognizable identity in the academic markets. However, there are some internal and external motivators for the institutions to collaborate with each other. According to Duffield et al. (2013), internal motivators are, for instance, leveraging resources, pooling talents, sharing common interests and solving academic problems through engaging with partner institutions in close proximity, physically and academically. External factors may include those opportunities causing institutions to collaboratively work on research grants or for accreditors, employers and state agencies (Kezar, 2005).

Normally academic institutions struggle for international collaborations to appear in the global radar (Altbach, Reisberg, \& Rumbley, 2009). Internationalization of institutions typically involves academic cooperation and knowledge transfer, and physical mobility of faculty and students through exchange programs. Academic institutions fostering relations with other academic institutions abroad accelerate the generation of new and culturally different ideas, 
academic practices and policies that supports institutional development and academic services they offer to potential stakeholders. In addition, institutions are able to gain financial benefits and credentials through different projects and research endeavors.

\section{Secondary Stakeholder: Non-Business Organizations}

Business schools are quite fascinated by serving business organizations than non-business entities like government, public sector or community service organizations. Ferlie, McGivern, and De Moraes (2010) argue that those business schools serving only business community are actually contributing in ethical, social and environmental damages to the society. To promote and motivate business schools to serve and collaborate with non-business organizations, the authors offered a public interest business school model that opposes the control and interests of business community. On the other hand, government and public sector organizations are relatively slower and less innovative than private sector organizations (Sørensen \& Torfing, 2011). Therefore, active engagements among business schools and public sector organizations would reinforce the development of public sector organizations and offer academic services that are favorable to social developments. In addition, collaboration with public organizations would also bring new social sciences knowledge of public interests.

Non-for-profit organizations like non-governmental (NGOs) and community-based service organizations (CBOs) volunteer in social activities and strive against corruption and irresponsibility of for-profit organizations (Dienhart \& Ludescher, 2010). These organizations also expect business schools to support and collaborate with them to incorporate social responsibility and sustainability in research and management education programs (Muff et al., 2013; Pless, Maak, \& Stahl, 2012). In this way, business schools would be able to undertake relevant research for social improvements and develop business graduates who are effective managers yet socially responsible individuals.

\section{Conceptual Collaboration Model for Business Schools}

Business schools are facing mounting pressures from business and non-business communities for ignoring necessary academic services that schools could offer to their stakeholders. Business schools were primarily established to serve businesses, but they have been narrowing down their services. More recently, non-governmental and community-based organizations have also highlighted issues of social developments and sustainability. These organizations expect business schools to rethink their academic services and consider solving different concerns of society in a larger context. It shows that stakeholders demand for the managerial leadership that fulfills needs of businesses and social developments. For this purpose, business schools first have to have a definite purpose, so called vision and mission, and identity stakeholders who they would serve. And then, business schools should initiate collaborations with them to provide academic services needed. In Figure-1, this study proposes a collaboration model that maps linkage with stakeholders based on vision and mission of the business school. 


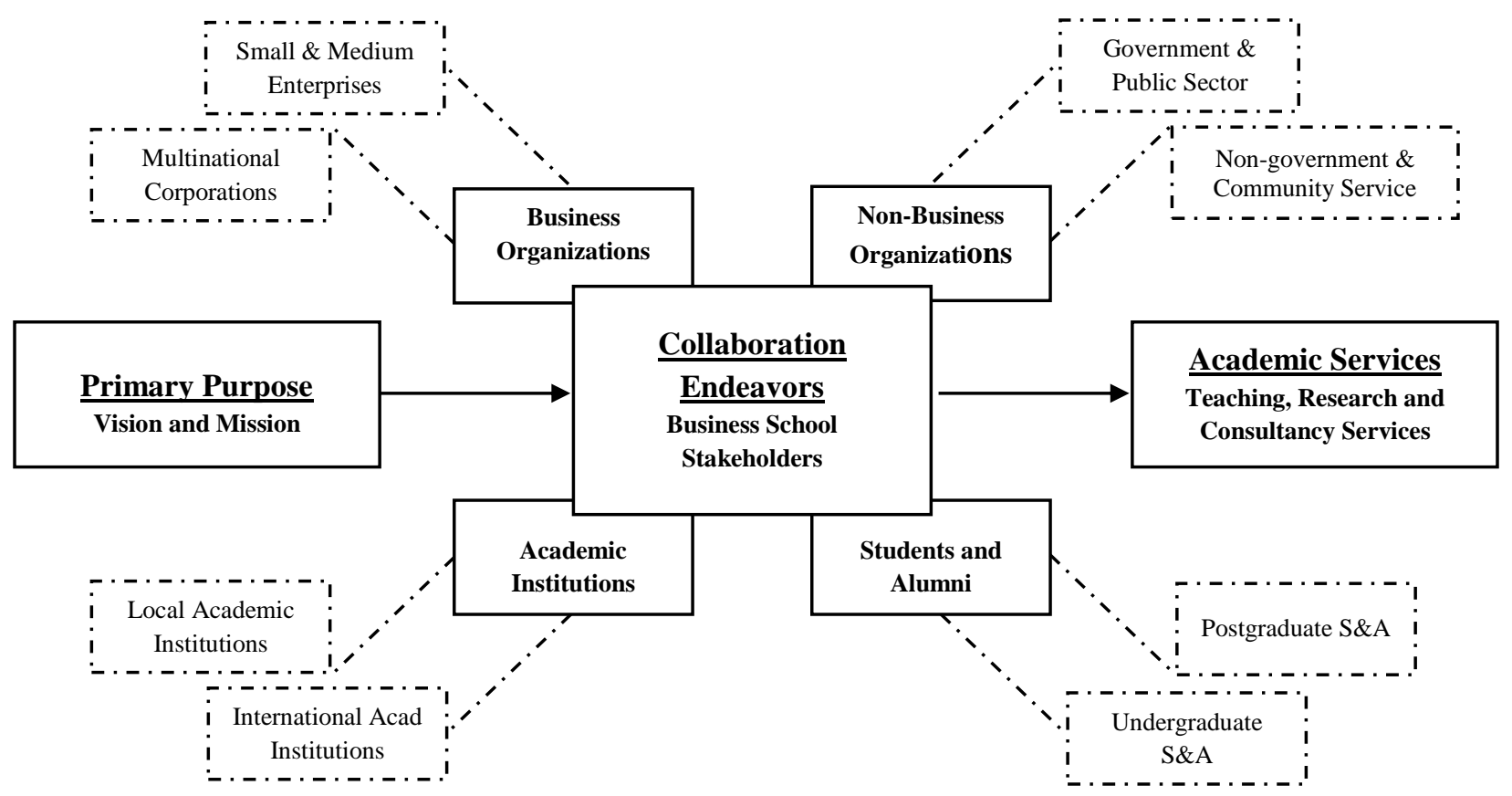

Figure 1: Conceptual collaboration model for business schools

Stakeholders in the conceptual collaboration model are divided into four broad segments, namely, business organizations, non-business organizations, academic institutions, and students and alumni. In each segment, there are some entities and individuals considered as stakeholders. For instance, business organizations consist of multinational corporations and small and medium enterprises; non-business organizations consist of government, public sector, non-government and community service organizations; academic institutions consist of local and international academic institutions; and finally, students and alumni of undergraduate and postgraduate academic programs.

The collaboration model presented in this study has some resembles with the concept of Phronesis offered by Antonacopoulou (2010), through which business schools could formulate the knowledge of stakeholders through reflexive techniques. But the conceptual collaboration model presented in this study also enables business schools and stakeholders to collectively produce viable outcomes in shape of academic services needed.

\section{Development of Collaboration}

Gray and Wood (1991) highlighted three levels of analysis for entities establishing collaborations, namely, preconditions, process and outcomes. In the context of collaboration model presented in this study, precondition refers to motivation or stimulus that cause business schools to collaborate with individuals and entities. Process involves stages to execute objectives of collaboration with partners. Outcome is academic services achieved through collaborations. Figure-2 illustrates the flow of levels of analysis based on suggestions by Gray and Wood.

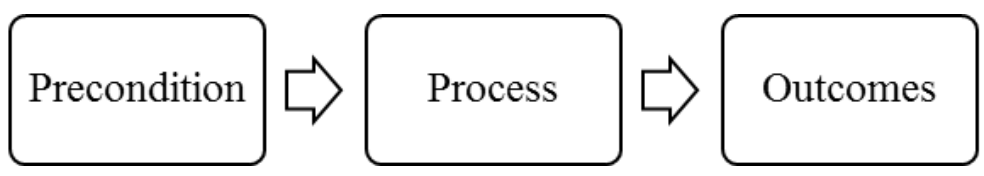

Figure 2: Levels of analysis for collaboration 
The precondition that could motivate business schools to collaborate with students and alumni is expectation. Students and alumni expect their graduate schools and degree programs to have reputation in academic markets, provide satisfactory business education and better future career after graduation (Baruch \& Sang, 2012). Business schools satisfying these expectations of students and alumni are likely to develop long-term relationships with them. Collaboration endeavors with students and alumni is relatively easier than collaboration endeavors with external entities, because business schools have an opportunity to initiate and manage formal as well as informal relationships with its primary stakeholders. Business school's collaboration with students and alumni in return would also bring better outcomes for the school. Students are most important stakeholders of business schools and they bring growth opportunities and economic benefits (Baruch, 2009; Thomas et al., 2013). Alumni could assist business schools in providing financial and political assistance (Weerts \& Ronca, 2008) and increase educational and social networks (Hall, 2011; Jarzabkowski, Giulietti, Oliveira, \& Amoo, 2012). Therefore, business schools and its primary stakeholders have prospects for developing a long-term and valuable relationships.

Recent authors argue that business schools are offering irrelevant academic services (Ghoshal, 2005; Khurana, 2010; Paton et al., 2014) and they are not producing ethically and socially responsible business graduates (Muff et al., 2013; Rasche \& Gilbert, 2015). Therefore, preconditions that stimulate business schools to collaborate with secondary stakeholders are satisfying the needs. To initiate collaboration, firstly business schools may need to identify those organizations and institutions who they would serve through specified academic services. Successful collaborations with secondary stakeholders may have to follow some formal processes. According to Thomson, Perry and Miller (2009), there are five constructs of formal collaboration, namely, governance, administration, mutuality, norms, and organizational autonomy. These constructs can be viewed in three major segments. The first two constructs, namely, governance and administration, are concerned with the structure of collaboration, including decision making, functions, rules, and administrative actions. The second two constructs, namely, mutuality and norms, are concerned with social issues like trust, reciprocity, shared and complementary interests of individuals and entities in collaboration. The last construct of organizational autonomy strategically balances the process with policies that bound the school with its partners. These construct could support formal collaboration of business schools with partners based on intended outcomes in shape of academic services.

To enable continuous knowledge sharing and learning in academic collaborations, trust is very important between individuals and organizations (Darabi \& Clark, 2012). Schilke and Cook (2013) developed a model for cross-level development of trust between entities in collaboration. The model contains four stages of trust development. First stage is individual-organization trust, in which partners gather clues about trustworthiness. The second stage is individual-individual trust, in which partners become acquainted through interpersonal interactions. The third stage is again individual-organization trust, in which partners transfer the trust. The final stage is organization-organization trust, in which partners institutionalize the trust. The authors argue that trust is important between all individuals in collaboration activities. Therefore, individuals engaged in collaboration must ensure trust in all specified levels. 


\section{Conclusion}

The value and relevance of academic services offered by business schools are being questioned by many recent authors. Major concerns are regarding fulfillment of expectations and needs of different stakeholders through academic services. For business schools, students and alumni are primary stakeholders and key products that schools offer to employer organizations. Secondary stakeholders are academic institutions, business and non-business organizations. However, there is lapse in the literature portraying a collaboration model that links business schools with all potential stakeholders, based on vision and mission of the school.

In order to rejuvenate the relevance of academic services, this study offers a conceptual collaboration model for business schools and also proposes method for development of collaborations. The model and methodology presented in this paper are based on relevant literature. Therefore, this concept needs further exploration and examination. It is recommended that future studies may expand this model by developing a theory of collaboration based on theoretical underpinnings and test the model in physical, contextual setting. Exploration of the model may bring several new ideas and concepts of collaboration in the context of business schools and management education programs.

\section{References}

Altbach, P. G., Reisberg, L., \& Rumbley, L. E. (2009). Trends in global higher education: Tracking an academic revolution. France: UNESCO.

Antonacopoulou, E. P. (2010). Making the business school more critical: Reflexive critique based on phronesis as a foundation for impact. British Journal of Management, 21(1), 6-25. http://dx.doi.org/10.1111/j.14678551.2009.00679.x

Austin, J. R., \& Bartunek, J. M. (2003). Theories and practices of organizational development. In W. C. Borman, D. R. Ilgen, \& R. J. Klimoski (Eds.), Handbook of Psychology (pp. 309-327). Hoboken, NJ: John Wiley \& Sons, Inc.

Bartunek, J. M. (2007). Academic-practitioner collaboration need not require joint or relevant research: Toward a relational scholarship of integration. Academy of Management Journal, 50(6), 1323-1333. doi:10.5465/amj.2007.28165912

Baruch, Y. (2009). To MBA or not to MBA. Career Development International, 14(4), 388-406. http://dx.doi.org/10.1108/13620430910979862

Baruch, Y., \& Sang, K. J. C. (2012). Predicting MBA graduates' donation behaviour to their alma mater. Journal of Management Development, 31(8), 808-825. http://dxdoi.org/10.1108/02621711211253268

Bruhn, M., Karlan, D., \& Schoar, A. (2010). What capital is missing in developing countries? The American Economic Review, 100(2), 629-633.

Canales, R., Massey, C., \& Wrzesniewski, A. (2010). Promises aren't enough: Business schools need to do a better job teaching students values. Wall Street Journal, 23, 1-4.

Darabi, F., \& Clark, M. (2012). Developing business school/SMEs collaboration: The role of trust. International Journal of Entrepreneurial Behavior \& Research, 18(4), 477-493. http://dx.doiorg/10.1108/13552551211239500

Datar, S. M., Garvin, D. A., \& Cullen, P. G. (2011). Rethinking the MBA: Business education at a crossroads. Journal of Management Development, 30(5), 451-462. http://dx.doi.org/10.1108/02621711111132966

Davis, J. H., Ruhe, J. A., Lee, M., \& Rajadhyaksha, U. (2007). Mission possible: Do school mission statements work? Journal of business ethics, 70(1), 99-110.

Dienhart, J. W., \& Ludescher, J. C. (2010). Sustainability, collaboration, and governance: A harbinger of institutional change? Business and Society Review, 115(4), 393-415. http://dx.doiorg/10.1111/j.14678594.2010.00369.x

Dixon, R., Slanickova, D., \& Warwick, P. (2013). Business school partnerships for globalization. Journal of Teaching in International Business, 24(3-4), 198-213. http://dx.doi.org/10.1080/08975930.2013.860350 
Duffield, S., Olson, A., \& Kerzman, R. (2013). Crossing borders, breaking boundaries: Collaboration among higher education institutions. Innovative Higher Education, 38(3), 237-250. http://dx.doi.org/10.1007/s10755-0129238-8

Ferlie, E., McGivern, G., \& De Moraes, A. (2010). Developing a public interest school of management. British Journal of Management, 21(1), 60-70. http://dx.doi.org/10.1111/j.1467-8551.2009.00681.x

Friga, P. N., Bettis, R. A., \& Sullivan, R. S. (2003). Changes in graduate management education and new business school strategies for the 21st century. Academy of Management Learning \& Education, 2(3), 233-249. http://dx.doi.org/10.5465/amle.2003.10932123

Ghoshal, S. (2005). Bad management theories are destroying good management practices. Academy of Management Learning \& Education, 4(1), 75-91. http://dx.doi.org/10.5465/amle.2005.16132558

Gray, B., \& Wood, D. J. (1991). Collaborative alliances: Moving from practice to theory. The Journal of Applied Behavioral Science, 27(1), 3-22. http://dx.doi.org/10.1177/0021886391271001

Hall, S. (2011). Educational ties, social capital and the translocal (re)production of MBA alumni networks. Global Networks, 11(1), 118-138. http://dx.doi.org/10.1111/j.1471-0374.2011.00310.x

Jain, S. C., \& Stopford, J. (2011). Revamping MBA programs for global competitiveness. Business Horizons, 54(4), 345-353. doi:http://dx.doi.org/10.1016/j.bushor.2011.03.001

Jarzabkowski, P., Giulietti, M., Oliveira, B., \& Amoo, N. (2012). We don't need no education - or do we? Management education and alumni adoption of strategy tools. Journal of Management Inquiry 22(1), 4-24. http://dx.doi.org/10.1177/1056492612460588

Kezar, A. (2005). Redesigning for collaboration within higher education institutions: An exploration into the developmental process. Research in Higher Education, 46(7), 831-860. http://dx.doi.org/10.1007/s11162004-6227-5

Khurana, R. (2010). From higher aims to hired hands: The social transformation of American business schools and the unfulfilled promise of management as a profession. Princeton, NJ: Princeton University.

Kieser, A., Nicolai, A., \& Seidl, D. (2015). The practical relevance of management research: Turning the debate on relevance into a rigorous scientific research program. The Academy of Management Annals, 9(1), 143-233.

Muff, K. (2013). Developing globally responsible leaders in business schools: A vision and transformational practice for the journey ahead. The Journal of Management Development, 32(5), 487-507. http://dx.doi.org/10.1108/02621711311328273

Muff, K., Dyllick, T., Drewell, M., North, J., Shrivastava, P., \& Haertle, J. (2013). Management education for the world: A vision for business schools serving people and the planet. Glos, UK: Edward Elgar.

Napier, N. K., Harvey, M., \& Usui, K. (2008). Management education in emerging economies: The impossible dream? Journal of Management Education, 32(6), 792-819. http://dx.doi.org/10.1177/1052562908319994

Nesteruk, J. (2012). Business teaching, liberal learning, and the moral transformation of business education. Organization Management Journal, 9(2), 114-119. http://dx.doi.org/10.1080/15416518.2012.687995

Okunade, A. A., \& Berl, R. L. (1997). Determinants of charitable giving of business school alumni. Research in Higher Education, 38(2), 201-214. http://dx.doi.org/10.1023/a:1024933720131

Paton, S., Chia, R., \& Burt, G. (2014). Relevance or relevate? How university business schools can add value through reflexively learning from strategic partnerships with business. Management Learning, 45(3), 267288. http://dx.doi.org/10.1177/1350507613479541

Pless, N. M., Maak, T., \& Stahl, G. K. (2012). Promoting corporate social responsibility and sustainable development through management development: What can be learned from international service learning programs? Human Resource Management, 51(6), 873-903. http://dx.doi.org/10.1002/hrm.21506

Rasche, A., \& Gilbert, D. U. (2015). What drives ethics education in business schools? Studying influences on ethics in the Mba curriculum. In A. Nill (Ed.), Handbook on Ethics and Marketing, (pp. 284-301). Glos, UK: Edward Elgar.

Schilke, O., \& Cook, K. S. (2013). A cross-level process theory of trust development in interorganizational relationships. Strategic Organization, 11(3), 281-303. http://dx.doi.org/10.1177/1476127012472096

Selen, W. (2001). Learning in the new business school setting: A collaborative model. The Learning Organization, 8(3), 106-113. http://dx.doi.org/10.1108/09696470110391202

Sørensen, E., \& Torfing, J. (2011). Enhancing collaborative innovation in the public sector. Administration \& Society 43(8), 842-868. http://dx.doi.org/10.1177/0095399711418768

Starkey, K., \& Tempest, S. (2008). A clear sense of purpose? The evolving role of the business school. Journal of Management Development, 27(4), 379-390. http://dx.doi.org/10.1108/02621710810866732 
Thomas, H., Thomas, L., \& Wilson, A. (2013). The unfulfilled promise of management education (ME): The role, value and purposes of ME. Journal of Management Development, 32(5), 460-476. http://dx.doi.org/10.1108/02621711311328255

Thomson, A. M., Perry, J., \& Miller, T. (2009). Conceptualizing and measuring collaboration. Journal of Public Administration Research and Theory, 19(1), 23-56. http://dx.doi.org/10.1093/jopart/mum036

Weerts, D. J., \& Ronca, J. M. (2008). Characteristics of alumni donors who volunteer at their alma mater. Research in Higher Education, 49(3), 274-292. http://dx.doi.org/10.1007/s11162-007-9077-0

Xie, C., \& Steiner, S. D. (2013). Enhancing management education relevance: Joint creation of knowledge between business schools and business. Business Education \& Accreditation, 5(2), 1-15. 